Email: population@pncampus.edu.np

eJournal Site: http://ejournals.pncampus.edu.np/ejournals/ajps/

\title{
[ORIGINAL RESEARCH ARTICLE \\ Remittances and Development: Mirage of Prosperity in Dalit Community of Kaski District
}

\author{
Prakash Upadhyay, PhD \\ Department of Anthropology, Prithvi Narayan Campus, TU, Pokhara, Nepal \\ Corresponding Author \& Email \\ Prakash Upadhyay; prak-socio@ hotmail.com \\ Article History \\ Submitted 15 July 2021; Reviewed 29 August 2021; Accepted 04 September 2021 \\ DOI: https://doi.org/10.3126/ajps.v1i1.43588
}

\section{Copyright Information: \\ Copyright 2022@ The Author(s). \\ The journal is licensed under a \\ Creative Commons Attribution- \\ ShareAlike 4.0 International \\ License. \\ (c) (i) (2) \\ Published by \\ Department of Population Studies \\ Prithvi Narayan Campus \\ Tribhuvan University \\ Pokhara, Nepal}

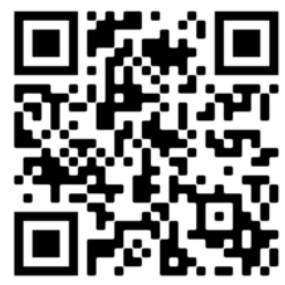

Scan to Access eJournal

\section{Abstract}

This article examines the propensities in international labour migration, remittances usage patterns and the influence of remittances on Dalit livelihood. Most Dalit groups of Nepal have their traditional occupational skills, but due to limited market access and the easy availability of cheap international products, their traditional occupations have been lost or threatened that has deteriorated livelihoods and the chances of development. Further, historic relegation, lower education levels, caste discrimination and sectarian hierarchy has curtailed better jobs opportunities in Nepal, compelling them to migrate abroad for work. Despite the role of remittances in alleviating caste/class discrimination and supporting family livelihoods, there has been a modest improvement in the human, educational and financial assets of Dalit households. The scenario of poor educational, economic, and human status, low participation in social and development sectors is evidence of the inability of remittances to solve livelihood problems. The rhetoric of permanent prosperity through foreign employment has proved a fiasco and a mirage of unsustainable prosperity rather than prospects of enduring genuine fortune. In the absence of productive and sustainable remittance use pattern, labour migration has become an addictive practice with high dependency on foreign labour and upsurge of consumerism that has created insecurity in livelihoods. A socioeconomic structural adjustment is mandatory to augment community economy along with human and social capital enrichment strategies that will pave the way to break the poverty and unemployment cycle. The prerequisites are the development and effective implementation of strategies 


\section{Remittances and Development: Mirage of Prosperity in Dalit Community}

that facilitate the maintenance of traditional skill-based jobs at home and policies using remittances.

Keywords: Social-cultural model, bidesh, remittance reliant, unsustainable prosperity

\section{Introduction}

The 2011 Nepal census recorded 126 different castes/ethnicities that speak 123 languages and exhibit mosaic of cultural and religious diversities/backgrounds. These groups include people of Indo-Aryan descent, whose traditional caste groups follow the Hindu caste system, and ethnic groups, mainly of Tibetan-Mongolian descent (CBS, 2011). The purported low caste Dalits are Hindu groups of Indo-Aryan origin from both hill and terai comprising 13.6 per cent of Nepal's total population (CBS, 2011). There are different subsets in the Dalit community. The Dalit Commission (2002) documented 28 cultural groups of Dalits from different hill sub-castes (Hill Dalits), Tarai (Tarai/Madhesi Dalits) and the indigenous Dalit Newar community of Kathmandu. There are four main groups of Dalits in Hills-Kami/Sunar (Blacksmith/Goldsmith), Damai (Tailor), Sarki (Shoemaker/Cobbler) and Gaine (Musician). These are groups of artisans with distinctive traditional skills. These artisan occupational groups are the most marginalized, the most backward and the underprivileged in Nepal. According to Nepal Human Development Report by National Planning Commission (2014), Dalits have been historically victimized and considered untouchable in the dominant Hindu socio-cultural model. Hence, they are vulnerable to poverty and backwardness. It is a marginalized community forced to stand at the bottom of the social structure and excluded from national development drifts due to caste discrimination and fundamental Hinduism. Historically, the caste system was introduced in the hills of Nepal by the Aryans of the Ganges plains of India during the medieval period by means of military superiority, ideological warfare, and astute foreign policy. Kathmandu Valley has its own caste system introduced in 14th century by King Jayasthiti Malla (Upadhyay, 2018). The echelon of caste structure led to caste-based divisions and the marginalization of Dalits in the mainstream political, economic, social, cultural, and educational spheres.

Though endowed with customary skills such as forging iron, gold, tailoring, shoemaking etc., in recent days, due to the lack of market understanding of traditional art and skills, customary craftsmanship, limited market access, and availability of cheap international products, many Dalits have abandoned their traditional craft. It has deteriorated their customary livelihoods, the means to provide the necessities of food, water, shelter, clothing, education etc. Lower educational attainment and caste/class discrimination also become obstacles to obtaining better jobs for Dalits, thus preparing the basis for their emigration to work abroad. Beyond India, many Dalits have gone abroad to work in countries like Qatar, Saudi Arabia, Dubai, Bahrain, Malaysia, South Korea, European countries, etc. Further, socio-political unrest, lack of infrastructure, increasing youth population, wage disparities, globalization and greater connectivity with broader world have encouraged the Dalit youths to leave for destination countries for earning. Not only the Dalits, numerous young people from different caste/ethnicities leave the country not only because they are jobless, poor, or otherwise, but to experience 'bidesh' with a dream of going overseas and gaining the experience of foreign employment - skilled or under-skilled and permanent or temporary - immediately after their eligibility to obtain a passport.

International labour migration officially began in Nepal in $\mathrm{AD} 1815$ with the recruitment of young Nepalese into the British Gurkha Brigade (Gurung, 1983; Thieme, Susan \& Wyss, 2005). Yet, it was not until the enactment of the Overseas Employment Law in 1989 that Nepalese workers began to migrate abroad to earn remittance. Kollmair 


\section{Remittances and Development: Mirage of Prosperity in Dalit Community}

et al., (2006) argues that this leads to significant international migratory flows outside India. According to Nepalese government estimates (2014), there could be around three million Nepalese, or around $10 \%$ of the total population, working abroad and repatriating money. Migration rates are much higher for young people and men. With an increase in international migration, remittances have increased over the years, although a report by The Himalayan Times (2016) paints a dismal picture of remittance flows. According to this report, money inflows to Nepal only increased by $5.7 \%$ to reach Rs. 342.2 billion in the first half of 2016/17, compared to a growth of $17.3 \%$ in the same period last year. However, according to another report by the same newspaper, remittances increased by 8.6 per cent in first eight months of 2020 in an era of COVID-19 global lockdown. Remittance inflow increased by 8.6 per cent to Rs. 642.14 billion in the first eight months of the fiscal year 2020 compared to the 1.5 per cent rise in the same period of 2019 (The Himalayan Times, 2021).

According to the World Bank (2016), excluding remittances received through informal channels, remittances received through official channels represent around $29 \%$ of Nepal's GDP. Nepal is the third largest recipient of remittances in terms of contribution to GDP in the world. Now, remittances have become a significant source of income for Nepalese households. Higher labour force growth and limited employment opportunities outside the agricultural sector are the main factors contributing to largescale migration from Nepal. The increase in the workforce due to job creation, low wages, and high demand for labour in industrializing Asia and the Gulf are other contributing factors. In addition, poverty and food scarcity are the determining factors of increased migration in the context of Dalits.

The use of remittances in Nepal to improve living standards has been documented by several studies (Wahidin, 1989, Seddon et al., 2001). Remittances are usually spent on land and housing. These are safe investments for households, but in macroeconomic terms, they are non-productive assets that have no lasting impact on the nation's real income. However, poverty reduction through remittances has helped diversify livelihoods, increase ownership, and acquire assets and capital. The increase in migration to work abroad contributed about a fifth to poverty reduction in Nepal between 1995 and 2004, but that it had a positive impact and insignificant effects on inequalities (Lokshin et al., 2007, 2010). Thus, while remittances provide benefits at household and community level, they cannot aid the long-term development of the country without planned management. The savings rate of Nepalese workers is lower because most of them work for low wages and their marginal propensity to consume is relatively higher. Only a small percentage of migrants use direct deposits for productive investments such as agriculture, manufacturing, and trade. Lokshin et al. (2010) affirm that the main forms of investment in remittances are children's education, reinvestment for continued migration, and cash lending. The resources and expertise of returning migrants can also be a good resource for the economic development of the country. Nepal does not have reliable data on the number of returning migrants.

Nepal Rastra Bank Survey (2007) of 832 households in 8 districts (half of which are in the Far West Development Zone) of Nepal affirm that the majority of families depend on remittance money. Most remittances are used to meet household needs and to repay previously borrowed loans. Remittance is also spent on real estate (land and housing). This is a safe investment but from a microeconomic point of view, they are obvious assets. Likewise, $47 \%$ of returning migrants acquired new skills by working abroad, but only $16 \%$ used these skills for income-generating activities after their return. The survey concluded that remittances provide no benefits at the household and 


\section{Remittances and Development: Mirage of Prosperity in Dalit Community}

community level and cannot help the country's long-term development without its strategic management.

The remittance and development literature identifies remittances as a potential but problematic source of economic development. Discussions in this area revolved around two themes (Taylor et al., 1996): (1) how remittances are invested in migrants' places of origin; and (2) whether remittances reduce or exacerbate inequality. The researchers sought to better understand the promoters, prosecutions, and benefits of remittances. Asking why one group benefits more from remittances than another can open up a more political discussion of the relationship between remittances and development, however, studies are scarce in this direction. One of the primary weaknesses of the remittances and development studies is that they focus nearly exclusively on economic impacts of remittances while questions of politics, society, religion, and culture are relegated to the margins.

Research on remittances and development often criticizes migrants for not making rational and efficient decisions about their remittances, as remittances are mainly spent on consumption - to meet daily demand while only a small part is invested in the manufacturing sector. Some expressed concern that remittances would lose their power as a tool for development if they were wasted on simple consumption. Yet blatantly normative statements like these sparkle with vivid answers. Migrants may not be the most suitable agents to tackle underdevelopment. Indeed, individuals often seek emigration as a survival strategy because their place of origin does not have significant development in the first place. Historically, the Dalits of Nepal were socially, culturally and economically victimized by the state and society, hence in order to visualize the impacts of remittances on development and livelihoods, an assessment may be necessary of their social, cultural, historical and personal conditions as well. The intentions of Dalit migrants regarding the purposes and uses of their remittances and use of their deposits can be justified, although they deviate from capitalist prospects of rational investment in productive sector. Previous studies on remittances and development leave little room for this possibility. Therefore, this current study of the Dalit community attempts to examine this issue by approaching the primary data obtained from the field. This study examines the usage patterns and effects of remittances on the Dalits' livelihoods, the truth about their livelihoods and understands how the different living conditions of the Dalits are affected by the amount of remittances. The main objective is to examine propensities in international labour migration and the influence of remittances on Dalit families.

\section{Data and Methods}

Based on primary field data from a small sample of Dalit households collected from western Nepal, this study was carried out in Salyan, a small village in Annapurna rural municipality (Gau Palika) of Kaski district. It is the largest Dalit settlement in this region with 137 Dalit households. These 137 Dalit households constitute the study universe, of which 86 Dalit households totally dependent on remittances were selected for the study. In the first step of the sampling process, a list of households was made to identify eligible respondents. Once the households were listed, only 86 respondents (one each from 86 households) were selected for the interview. The interviewees were the household heads ( 81 females and 5 males) from each household receiving remittances. These heads of household are the main decision makers of their families. Data was collected through semi-structured personal interviews (closed and open questions) and observations. Closed questions were used to collect information on households and individuals, while open-ended questions were used to understand patterns of remittance 


\section{Remittances and Development: Mirage of Prosperity in Dalit Community}

use and their impact on livelihoods. Field surveys for data collection were completed between January 10 and 29, 2020.

\section{Migration, Remittance and Livelihood: Theoretical Outlook}

Implanted in theoretical underpinning of New Economics of Labour Migration (NELM) framework, this study examines the remittance receipt by Dalit households. The neoclassical microeconomics focuses on individuals' relative earning potentials in origin and destination with a conviction that individuals migrate when the expected gain from migrating to a destination is greater than that from staying in the origin (Hay, 1980). NELM framework holds the notion that, migration of individuals is a family-based decision and is an attempt to diversify household income portfolios to protect against risk and gain access to capital to finance consumer and productive purchases (Stark, 1991; Stark \& Bloom, 1985; Stark \& Taylor, 1991). Accordingly, the choice to migrate by household members is a family approach to reduce risks/uncertainties. Sana \& Massey (2005) affirm that by making such a choice and decision, a household makes an investment in migration and in return, the household expects to receive remittances.

On sending remittances, there are three arguments to explain whether a migrant will remit or not: altruism, self-interest, and insurance and risk-sharing (Arun \& Ulku, 2011). It is assumed that migrants are fretful about their family members back home. Liang, Li \& Ma (2013) argue that migrants send remittances for the well-being of household members who are left behind (altruism motive). It is also anticipated that a household will send members to destinations with high earning potentials with the hope of receiving higher remittances and in return high remitted amount will be used by the family members. However, Seddon et al. (1998) claim that the destinations with higher earning potentials are most likely hardest to be reached. But when the migrants are successful to get there and get a job, the earning prospects are higher and consequently the purchasing power of the family members will surge. Arun \& Ulku (2011) argue that migrants' earnings are one of the important determinants of whether one remit or not and the amount of remittances sent. The earning potentials of migration diverge by destinations hence it is expected that the remittances received by a household from migrants and its uses and effects will also vary by migrants' destinations.

\section{Remittances Role in Growth and Development: Reverie of Lavishness}

Of the studied population, there are around 82 (95.5\%) households of Kami, 3 (3.5\%) households of Damai and only one house (1.0\%) of Sarki (Cobbler) family. Almost $97.5 \%$ household heads are married. The average family size is five members. Altogether 81 heads of household are housewives involved in home and agricultural works. Only five males lead their families (their wives work abroad) of which two are involved in skilled occupation of iron smithy in the village whereas three males are redundant. Considerable bulk of professionally inert woman depicts the picture of high dependency on remittances and reluctance to find jobs at home due to easy availability of foreign remittances. Around $42(49.0 \%)$ households have at least one of their family members employed in Qatar and 27 (31.3\%) in Saudi Arab. Similarly, 15 (17.7\%) are employed in Malaysia, Dubai and Kuwait, and the rest are in Korea and Spain.

The growing trend of foreign labour and the accumulation of remittances have made remarkable changes in the livelihoods of the house and the community. Foreign migration has proven to be an effective strategy for the adaptation of livelihoods to create financial and human capital contributing to the mitigation of poverty. Most migrant workers remit 30,000 to 45,000 Nepalese rupees (\$300 to \$450) per month. The remittances have contributed considerably to the economic development of the 


\section{Remittances and Development: Mirage of Prosperity in Dalit Community}

family and have a significant and positive impact on daily socio-economic life contributing to positive economic development of the family, changed lifestyle, improved standard of living, reduced poverty and challenged the prevailing caste-based discrimination. Remittance has diversified family work patterns and reduced the risk and dependencies on single economic activities and some of the family adaptation strategies used to optimize the family rather than individual well-being.

Despite the differences in receipt of remittances, the monthly expenses of the family depend on family size and expenses pattern. Around seventy per cent families have used the remittances for expenses on gratifying basic needs such as food, children's education in private English Boarding schools, everyday expenditures like medicines, clothes, house repair, festival celebration or purchase of farmland. They spend around 25,000 Nepalese rupees in celebrating Hindu festivals like Dashain and Tihar. Remittances have empowered them to live an affluent life. It is contributing to economic and social development and has enhanced the living standard of the household facilitating a higher level of consumption and increased educational opportunities for the children. Consumption itself is not a productive activity, but the increased consumption has improved productivity by improving health and improved the capacity of young children to acquire a better education that can contribute to societal development. About thirty per cent families were able to make a decent saving of the remittances. They have taken the membership of various cooperatives and have bank accounts to bond their money and able to capitalize their money for different monetary resolutions to accumulate/surge assets. This financial strengthening has helped to strengthen social relations with upper caste people through money lending and participation in rituals (birthday celebrations and marriages) that has ensued in the decline of caste-based discriminations, and has aided to sustenance of their bargaining capacity, physical, psychological and social development.

Conventionally, the mainstream Dalits were landless peasants working for landlords. Remittance has aided them in procuring land. Many Dalits households have used the remittance for the accumulation of land. Currently, $54(63.0 \%)$ households own $1000-2000$ sq. $\mathrm{m}$ and 4 (4.6\%) households have 2000-4000 sq. $\mathrm{m}$ landholdings. Likewise, 9 (10.4) households have 4000-6000 sq. $\mathrm{m}$ and the rest 22 per cent possess more than 6000-8000 sq. $\mathrm{m}$ landholdings. This figure depicts piercing differences in landholding pattern in Dalit settlement that points to insecure livelihood and economic inequality within Dalit communities. Compatible to the theoretical perspective of NELM framework, the grossing possibilities of migration vary by destinations (migrants employed in South Korea, Spain, Malaysia send higher remittances), and hence the remittances received by a household determined the magnitude of landholding at households' level. Remittance uses has also helped many to construct houses. Though there are economic, social and cultural motives behind labour migration, this has become an obsession in Dalit community. They prefer a foreign job rather than seeking local jobs---an addictive appetite that is killing customary occupations and has speeded foreign dependency. Yet, there has been a significant sway on and contributions to the social security and economic development of Dalit folks, more precisely remittance has abetted a domineering part in lessening poverty and enlightening living status of families, gratifying rudimentary needs, altering living standards, improving access to better education and better-quality health maintenance and wellness. Economic empowerment has made them more confident than ever, to take positive decisions in the community and family. Social remittance such as behaviour, ideas, identities and social capital that has flown from remittance destination country to Dalit community has proved to be the catalyst for financial empowerment, improved credit constraints, improved the allocation 


\section{Remittances and Development: Mirage of Prosperity in Dalit Community}

of capital, financial development and thus accelerated socioeconomic and cultural growth. They are at enhanced position to complement social capital, win social trust and increase admiration, self-respect, social response, and civility.

Despite diverse constructive impacts of remittances, only few families have good consciousness of decent health, nutrition, and safe environment. The whole village lacks able-bodied youths with only few young men left in the village. Further, they have trivial participation in social, development and economic activities in their vicinity. Dearth of efficient human resources has resulted in decline in agricultural productivity. Barren agricultural fields can be seen here and there in the village. Absence of active male's labour force has resulted in the constricting down of livestock holding in the village. Many families have left agriculture and condensed the livestock size after their family members migrated as migrant worker. Labour migration has exerted an adverse brunt on animal husbandry and agriculture. Many migrant workers have been cheated by manpower agencies and agents.

The culture of poverty is a design or a style for living with certain values which is communicated from one generation to another. Battered by the state and stifled by caste discriminations for generations, the Dalit folks are the victims of culture and poverty that have adverse brunt on their people. With fatalistic and prodigal values, they are facing scrupulous hecklings in benefiting from remittances. With a very poor educational status and high cost-of living, they have very insufficient engrossment in social, development and economic sectors despite the receipt of remittances. Beginning of the remittance reliant magnanimous lavish culture is a part and parcel of Dalit life. With high school dropouts among the Dalit students, early marriage and alcoholism are the emerging new challenges. About sixty-five per cent households have had unpleasant experiences of alcohol use. Both male and female have the consistent habit of alcohol, smoking and tobacco use consequently resulting in economic crisis and poor social development leading to licentious utilization of remitted money. Also there will be an obligation for medical treatment and will have to capitalize transmittal money on medical treatment. Family wrangle owing to liquor use and the meagre emotional attachment between the migrants and their family members is a primary problem. About fourteen per cent households have the delinquency of family wrangles owing to alcohol uses and poor emotional attachment between the migrant and family members especially between spouses.

Despite the instances of remittance misappropriation, the broad ramifications of remittance have been positive on the wellbeing of recipient families- fulfilling basic needs that has helped combat poverty, made them free from financial worries hence making a better living in the society where they were underprivileged culturally, socially, and economically for centuries. Remittance has contributed to social change, economic development, improved living standards, changed lifestyles and increased the confidence level. The family members staying behind at home are relishing an honoured standard of living that has been possible only through remittances. Migration for foreign labour has become a measure of the family adaptive stratagem to expand the family's pattern of labour use to maximize family welfare. The missing labour at home was remunerated by remittance of migrant. Hence, remittance has provided motivation for human development in diverse ways. Beyond the economic remittances, it has supplemented innovative ideas, behaviour, individualities, societal stature and beyond all-social and economic empowerment. Remittance receiving households' expenditure and the process of purchasing and consumption of products and services can be defined as an investment in human capital. It is a kind of reliance on foreign employment that has led to ostentatious unproductive use of remittance at hand. This transmittal money has helped 


\section{Remittances and Development: Mirage of Prosperity in Dalit Community}

in abridging paucity and increased the access to health and education services. But productive investment and entrepreneurship could have amplified employment opportunities in local community that would have contributed to long-term supportable advancement of families. Hence the discrepancy in productive and unproductive remittance use pattern need to be examined in a new way. However, the minor fraction of remittance used for impending saving or on other meticulous asset like children's education and health can be assumed as venture in future social capital. Insensitive to utilize the remitted money for future livelihood security or any commercial activity is a serious issue to be deliberated.

\section{Conclusion}

As a stratagem to tackle unemployment, underemployment and many other sociocultural and economic problems, Dalit labour migration is a family decision, a domestic strategy to reduce risk/uncertainty in order to diversify household income portfolios to hedge risks and access benefits, capital gains to future consumption and product purchases and in return, the household receives a deposit for the welfare of the family members left behind---an altruistic motive. However, as the majority of remittance recipients are better consumers, there has been very little use of remittances in long-term productive investment, henceforth there has been little improvement in their human, educational, productive assets and livelihood security. While income from remittances has helped alleviate scarcity at a faster rate and improve household's living standards, the overall self-sustained and self-sustaining economic growth of the community has not been constructive. Remittance has exacerbated foreign dependency, undermined local economic assets and income generating productive activities. The long-term absence of migrant workers has wielded negative social effects and has surged the growth of deviant activities such as alcoholism and family breakdown. The emigration of prolific young people cannot be a long-term social and economic solution for the family and society. It does not bring any productive social or technological change in the native village, but only alter the consumption habits via remittance triggered lavish consumerism that cause heavy damage to agriculture, local industries, traditional occupations/manufacturing sectors and trap the society in the vicious circle of remittance addiction. This whole situation constructs insecurity and uncertainty in livelihood status and social security of households, hence remittances should not be seen as a supernumerary for productive investment and merchandizing.

Labour migration is the part and parcel of global liberal economy where nationhood is demeaned and foreign employment is an obsession. Ease of transportation, surge of information and ambitions of foreign employees getting momentum through changing lifestyles all construe foreign employment an inevitable global phenomenon-a mirage of unsustainable prosperity not an opportunity or prospect for all-round development of community and country. The requirement is that remittances should be used in sustainable alternative production that generates income rather than heavily invested in lavish consumer spending. Therefore, investment opportunities of remittances must be created by the government and non-governmental sectors. Basically, the government should push money remitters to start tax-free local businesses based on their traditional skills and traditional crafts in the form of skill-based trades that have been honed at home. In addition, the development and effective implementation of pro-poor employment strategies and awareness raising among Dalits are urgently needed. Government should work towards a vibrant rural transformation and rural entrepreneurship that can help address Dalit labour outmigration. But, it should be eased by solid policy reforms. 


\section{Remittances and Development: Mirage of Prosperity in Dalit Community}

\section{References}

Arun, T. \& Ulku, H. (2011). Determinants of remittances: The case of the South Asian Community in Manchester. Journal of Development Studies, 47(6), 894-912. https://doi.org/10.1080/00220388.2010.527951

Central Bureau of Statistics. (2011). National Population and Housing Census 2011 (Vol. 02). Central Bureau of Statistics, Kathmandu.

Government of Nepal. (2014). Labour migration for employment: A status report for Nepal: 2013/2014. Kathmandu: Ministry of Labour and Employment, Department of Foreign Employment.

Gurung, H. B. (1983). Internal and International Migration in Nepal. Kathmandu, Nepal: HMG Population Commission.

Hay, M. J. (1980). A structural equations model of migration in Tunisia. Economic Development and Cultural Change, 28, 345-358.

Kollmair, M., Manandhar, S., Subedi, B. \& Thieme, S. (2006). New figures for old stories: Migration and remittances in Nepal. Migration Letters, 3(2), 151-160.

Liang, Z., Li, J., \& Ma, Z. (2013). MIGRATION AND REMITTANCES. Asian Population Studies, 9(2), 124-141. https://doi.org/10.1080/17441730.2013.785721

Lokshin, M., Bontch-Osmolovskim, M., \& Glinskaya, E. (2007). Work-related migration and poverty reduction in Nepal. World Bank Policy Research Working Paper No. 4231, Washington, DC: The World Bank.

Lokshin, M., Bontch-Osmolovskim, M., \& Glinskaya, E., (2010). Work-related migration and poverty reduction in Nepal. Review of Development Economics, 14(2), 323-332, GRIPS Policy Research Center.

Nepal Rastra Bank Survey. (2007). A study on remittance from India. Kathmandu: Nepal Rastra Bank,

National Planning Commission. (2014). Nepal Human Development Report 2014: Beyond Geography, Unlocking Human Potential. Kathmandu, National Planning Commission, Government of Nepal and United Nations Development Programme.

Sana, M. \& Massey, D. (2005). Household composition, family migration and community context: Migrant remittances in four countries. Social Science Quarterly 86(2), 509-528.

Seddon, D., Adhikari, J. and Gurung, G. (2001). The New Lahures; Foreign Employment and Remittance Economy of Nepal. Institute for Development Studies (NIDS). Kathmandu, Nepal.

Stark, O. (1991). The migration of labour. Oxford: Basil Blackwell.

Stark, O. \& Taylor, J. E. (1991). Migration incentives, migration types: The role of relative deprivation. The Economic Journal, 101(408), 1163-78.

Stark, O. \& Bloom, D. E. (1985). The new economics of labour migration. American Economic Review, 75(2), 173-178.

Taylor, E., Arango, G., Hugo, A., Kouaouci, M., Douglas, A.P. (1996). International migration and community development. Population Index, 62(3), 397-418.

The Himalayan Times. (2016). Nepal Top Remittance Economy in Proportion to GDP in Asia in 2016. Kathmandu, December 7.

The Himalayan Times. (2021). Remittances Rise by 8.6 per cent in First Eight Months. Kathmandu, April 13, 2021. 


\section{Remittances and Development: Mirage of Prosperity in Dalit Community}

Thieme, S. \& Wyss, S. (2005). Migration patterns and remittance transfer in Nepal: A case study of Sainik Basti in Western Nepal. International Migration, 43(5), 5998. doi.org/10.1111/j.1468-2435.2005. 00342.x

Upadhyay, P. (2018). International Labour Migration, Remittance and Impacts on Livelihood: A Case Study of Dalit Community in Western Nepal. In Migration and Human Security in South Asia. Adroit Publishers, New Delhi, India. http://www.adroitpublishers.com/

Wahidin, M. (1989). Impact of Overseas Labour Migration on Bangladesh Economy: Macro and Micro Evidences: A Macro Economic Perspective. In R. Amjad (Ed.), To the Gulf and Back: Studies on the Economic Impact of Asian Labour Migration (pp.16-29). New Delhi: ILO/ARTEP.

World Bank. (2016). Migration and Remittances Factbook 2016. Third Edition. Washington, DC: The World Bank. http://doi.10.1596/978-1-4648-0319-2 